\title{
ARE OUR CURRICULA STILL RELEVANT?
}

\section{J C Beenhakker}

\begin{abstract}
Summary
Very fow physiotherapists are concerned with community health and the care of the elderly has a low priority amongst members of our profession. In a recent survey of our universities, it was found that very little time was allocated to preventive health and even less time was spent on gerontology during student training. All member organisations of the W C $P T$ have been requested to place greater emphasis on geriatric care at pre-qualification level as well as in physiotherapy practice. The need to change our attitudes towards the elderly are discussed and ideas on preventive and promotive health are presented for possible inclusion in the undergraduate curriculum.
\end{abstract}

I do not believe that our universities are training students to meet the ever changing health needs of the communities that they should be serving. Our students are, on the whole, most competent to work in well equipped hospitals which give them a licence to practice abroad, but very few of our schools are providing an opportunity for students to experience the various aspects of care in the community.

One of the biggest problems facing the world today is the increasing number of elderly people in the general population. In First World countries the percentage of persons over 65 years of age varies from $11-15 \%$ of the total population. Although this is much lower in South Africa at present, the number of elderly people in our country is expected to quadruple, from 1.5 million to 6 million, in the next $35-40$ years. ${ }^{1}$

Why are there so few physiotherapists in South Africa involved in or even interested in geriatric care? An article in the June Physio Forum inviting physiotherapists to share information or even form a special Interest Group in geriatric care only elicited two responses. In a recent survey of universities offering physiotherapy education, it was found that very little time was devoted to gerontology during the four years of training. Six of the seven universities felt that it was necessary to provide some form of post-qualification courses in geriatric care. Three however queried whether there was sufficient interest in this field and two stated that they did not have the facilities or expertise available.

What we need to do is inculcate in students a positive attitude towards the elderly right from the beginning of training. In a survey by Finn, it was shown that although the attitude of Dublin physiotherapists towards the aged was very positive, there were less favourable feelings regarding geriatrics. ${ }^{2}$ They felt that the rehabilitation of the elderly was very difficult because of the multiple pathology in these patients and lack of motivation, and only $9.1 \%$ of those surveyed were prepared to work on a long-term basis in geriatric care. Even more alarming was the fact that $78 \%$ considered geriatrics to have a low status amongst medical and supplementary health personnel. This hardly seems justified if one considers the number of books, journals and reports written by doctors and physiotherapists, which have been published recently in this area.

We need to move away from this stereotyped notion of low status by being positive about ageing ourselves and instil enthusiasm amongst our students in this field. We must not forget that the elderly have life's experiences and wisdom to share, if only we would listen, and many of man's greatest feats in history were achieved in their

\begin{abstract}
Opsomming
Daar is 'n groot tekort aan fisioterapeutiese dienste in die gemeenskap en veral die versorging van bejaardes geniet baie min aandag. In 'n onlangse opname wat aan ons universiteite gedoen is het dit geblyk dat baie min tyd spandeer word gedurende die opleiding van studente aan voorkomende gesondheid en nog minder tyd aan gerontologie. Alle lid-organisasies van die W C P $T$ is versook om groter klem te laat val op geriatriese versorging gedurende die kwalifiserende jare van studente asook in die praktyk. Die noodsaaklikheid om ons houding jeens bejaardes te verander word bespreek en idees cor voorkomende gesondheid word gegee met die oog op die moontlike insluiting daanan in die voorgraadse leerplan.
\end{abstract}

so-called senior citizen years. Working with the elderly may be a great challenge but it is always rewarding.

In order to allow the elderly to be as functional and as independent as possible within their own communities, physiotherapists should be planning and implementing community education programmes which emphasize health promotion and prevention. In the survey of universities it was found that the time spent on health promotion during student training ranged from 2 hours of theory to comments that this was covered in several subjects while students were in hospitals and clinics. Only two universities appear to be doing some health education in the community, the nature of which was not specified.

Education programmes need to be set up in our various communities taking into account the local demography of the community and any related epidemiological studies. These programmes must stress health promotion and the prevention of impairment of function. Some possibilities would be:

1. Exercise programmes and physical fitness guidance classes should be run in old age homes, service centres and clubs for senior citizens. In Stockholm up to 500 elderly people may gather on a summer evening for group exercises done to music and given by a physiotherapist. ${ }^{3}$

Exercises provide not only physical improvement but also meet a social need. It has been found that the maintenance of physical activity can bring about a 10-21\% increase in muscle strength, decrease the rate of osteoporosis and slow down the decline of glucose tolerance. ${ }^{4,5}$ Regular exercises will also prevent the accumulation of body fat, improve oxygen uptake and promote a feeling of well being. ${ }^{6}$ The improved social image and increased socialization resulting from group exercises and activities will obviously improve the quality of life of these senior citizens. Everyone needs advice about how often exercises should be done and how much is safe. Physiotherapists need to include, in their exercise classes, an explanation of the benefits of regular activities such as walking or swimming and should encourage the participants to take up hobbies and activities that will keep them mobile, improve their balance and co-ordination and thus improve their independence.

2. Pre-retirement advice. Many institutions and firms run pre-retirement planning courses. Are physiotherapists involved in these programmes, and if not, should they not be so involved? At the Baycrest Centre for Geriatric Care in Canada, a health maintenance and promotion department is available and is headed by a physiotherapist. ${ }^{3}$

- J C Beenhakker Dip PE, PhD,BSc (Physiotherapy), Associate Professor Department of Physiotherapy, University of the Witwatersrand 
3. Life style education. This should predate retirement by many years and should be a multidisciplinary venture. Posture awareness, back care and regular activity should be started in early adulthood so that it becomes a way of life for all our citizens. A correct diet should be stressed and advice on the deleterious effects of alcohol abuse and smoking should be given. Other areas that could be included are stress management and safety guidance. In addition it is estimated that 1 in 3 people over 60 years who are living in the community fall each year. ${ }^{7}$ The environmental risk factors which may lead to falls should be explained so that these may be reduced.

4. Education programmes at a tertiary level of prevention. Once patients have been discharged from hospital they will need to be taught how to maintain mobility and function in order to improve their independence. It is therefore essential for physiotherapists to visit the patients at home to establish what will be needed in the way of appliances or modification of the home environment in order to maintain activity. Self-help programmes can also be given so that the patients or care givers can be shown how to relieve pain, decrease stiffness and maintain function. Exercise, sport and hobbies should be discussed and patients encouraged to join clubs or service centres.

In order to meet these challenges of health care, there will need to be a change in emphasis in our undergraduate curricula. The curricula may vary from centre to centre as they should be designed to meet the specific requirements of the communities that the university will serve.

Gerontology, which is the science and study of ageing needs to be stressed throughout training. This should include the physiology of ageing and the social adaption to ageing and to increased loss of independence. Human development should not be confined to the child, as is done at present,but should be taught as a continuum throughout all stages of life. In the survey of universities it was found that the theory devoted to gerontology ranged from 3 to 10 hours only during the four years of study. If so little emphasis is given to this subject, is it surprising that out students perceive it to be of little importance?

The effects of accumulating pathology associated with ageing also needs to be covered in the curriculum. In the Sencare project it was estimated that 3-9 chronic diseases may be present in the elderly, with a concomitant increase in the number of pills taken and resulting in many side effects which aggravate the basic problem. ${ }^{1}$ It was found that the most common complaint in the elderly was osteoarthrosis which was present in $71 \%$ of the patients seen in the geriatric clinic at Tygerberg Hospital.

This was followed by Ischaemic heart disease (54\%), high blood pressure (35\%) and chronic obstructive pulmonary disease (30\%). Most of these conditions can be improved or even prevented by exercises and education programmes started in early adulthood.

It was interesting to note that although many people associate old age with senile dementia and depression, these only accounted for $18 \%$ and $10 \%$ respectively of the number of chronic illnesses. Many of these psychogeriatric conditions can be improved by social contact and the feeling of being wanted.

In the rehabilitation of patients with multiple pathology it is essential that students should be taught to assist the elderly people in prevention and self management of their problems. Students will need skills to clarify and solve the functional problems, rather than planning treatment based on one or more medical diagnosis. "Elderly people do not have time to spare," and students must be encouraged to establish "the patient's perception of the problems and work out with them ways to solve them." ${ }^{3 p 11}$

Very few of our universities are providing clinical experience in the area of the healthy elderly. Most students are only exposed to older patients who have COPD following strokes or who have sustained a fractured neck of femur.

The students are therefore missing out on the fun experienced when working with the healthy in old age homes or retirement villages and in social clubs. The number of clinical hours spent in geriatrics specifically by students varies from $0-40$ hours at the different universities. The WCPT in their report on ageing recom- mends that at least 160 clinical hours should be devoted to working with individuals and groups of elderly people. ${ }^{3}$

There is a need to draw up multidisciplinary educational programmes for the various communities. This will require an understanding of the roles of other health care workers and the ability to function as a member of a team in the design, implementation and evaluation of such programmes. Of equal importance is the development of teaching skills at undergraduate level as so many of a physiotherapist's tasks concern teaching the patient or client, his family or care givers and less qualified health personnel. We cannot expect students to acquire these skills through osmosis and a teaching module must be included in the curriculum.

Research needs to be encouraged at both undergraduate and postgraduate level as the health needs of elderly world wide are poorly defined. A good deal of research is being undertaken by other professionals but very little is coming from physiotherapists. Students at four of the universities have investigated certain aspects in the elderly population but much more needs to be done. We need to co-ordinate the research at our various universities and plan country wide projects to obtain more valid and relevant data. We need to find out about the health and welfare of the elderly in our own communities, the number of elderly in the community living at home, in retirement villages and in old age homes, and what their needs are. It is also important to establish the effects of exercise in middle-age and in the elderly on function and activities of daily living.

What is needed is for students to spend more time in the community so that they will be more adequately trained to meet the present and future health needs of the country. The time has also come for us to foster a positive attitude towards the elderly right from the beginning of training so that physiotherapists will want to specialise in this field to the same extent as most of our present students wish to go into sports medicine. Finally we must combine the data arising out of our research reports and pool our other resources in order that we may plan effectively for the year 2000 and beyond.

\section{References}

1. Wicht $\mathrm{CI}$, Prinsloo FR, Skibbe $A$ et al. An investigation into the health services for and the related needs of the aged. Sencare Project HSRC Pretoria 1989.

2. Finn AM. Attitudes of physiotherapists towards geriatric care. Physiotherapy 1986:72(3) 129-131.

3. WCPT. The role of Physical Therapy in the care of elderty people. WCPT London 1989.

4. Meiring $P$ de $V$. Towards independence in later years. In: Meiring $P$ de V Ed: Textbook of Geriatric Medicine. Juta and Co. Ltd. 1990.

5. MacRae PG, Richards NL. Effects of exercise on the physiology of ageing. In Exercise, falls and older adults. HSRC Pretoria 1989.

6. Noakes T D. Physical activity and ageing. South African Joumal of Physiotherapy 1983: 39(4) 88-92.

7. MacRae PG. Falls amongst older adults. Etiology and prevention. In Exercise, falls and older adults. HSRC Pretoria $1989{ }^{\circ}$

\section{ERA AGENCY LTD}

(Medical Services)

Coming to the UK? When you arrive please call on us. We have been giving a professional and friendly service placing Physiotherapists throughout the UK for over 20 years.

Second Floor, 14/16 Great Portland Street, London W1N 6BL

Telephones (071) 636-7414, (071) 637-0507, (071) 580-8915. 